\title{
PENGARUH PERLAKUAN FERMENTASI DAN AMONIASI KULIT SINGKONG TERHADAP NILAI KECERNAAN BAHAN KERING DAN BAHAN ORGANIK RANSUM PADA DOMBA JANTAN
}

\section{The Effect of Fermentation and Ammoniation of Cassava Peels on Digestibility Value of Dry and Organic Matter in Male Sheep}

\author{
Agung Dwi Nugroho, Muhtarudin, Erwanto, Farida Fathul \\ Departement of Animal Husbandry, Faculty of Agriculture, University of Lampung \\ Jl. Prof. Dr. Soemantri Brojonegoro No.1 Gedong Meneng Bandar Lampung 35145 \\ e-mail : agungdwinugrohooo@gmail.com
}

\begin{abstract}
This research aimed to determine the effect of fermentation and ammoniation treatment of cassava peels on ration on dry matter digestibility (DMD) and organic matter digestibility (OMD) in male sheeps. This research was conducted in May--June 2019 in the cage unit and the Laboratory of Nutrition and Animal Feed, Department of Animal Husbandry, Faculty of Agriculture, University of Lampung. The experimental design applied was a completely randomized design (CRD) with 3 treatments and 3 replications. The experimental unit used were 9 sheeps. The treatments given were ration $+15 \%$ cassava peels without treatment (R0), ration $+15 \%$ fermented cassava peels (R1), and ration $+15 \%$ ammoniated cassava peels (R2). The results showed that the use of cassava peel fermentation and ammoniation treatment had a significant effect $(\mathrm{P}<0.05)$ on dry matter digestibility (DMD) and organic matter digestibility in male sheep. The average of total digestibility of dry matter and organic matter of ration showed an increase of digestibility. The treatment of fermentation and ammoniation gave the best effect when compared to that without processing.
\end{abstract}

Keywords: Ammoniation, Fermentation, Cassava peels, Dry matter digestibility and organic matter digesbility, Sheep

\begin{abstract}
ABSTRAK
Penelitian ini bertujuan untuk mengetahui pengaruh perlakuan fermentasi dan amoniasi kulit singkong pada ransum terhadap kecernaan bahan kering (KCBK) dan kecernaan bahan organik (KCBO) pada ternak domba jantan. Penelitian ini dilaksanakan pada bulan Mei--Juni 2019 di unit kandang dan Laboratorium Nutrisi dan Makanan Ternak, Jurusan Peternakan, Fakultas Pertanian, Universitas Lampung. Rancangan percobaan yang digunakan yaitu Rancangan Acak Lengkap (RAL) dengan 3 perlakuan dan 3 ulangan. Unit percobaan yang digunakan yaitu domba sebanyak 9 ekor. Perlakuan yang diberikan antara lain Ransum $+15 \%$ kulit singkong tanpa pengolahan (R0), Ransum $+15 \%$ kulit singkong fermentasi (R1), dan Ransum $+15 \%$ kulit singkong amoniasi (R2). Hasil penelitian menunjukkan bahwa penggunaan perlakuan fermentasi dan amoniasi kulit singkong memberikan pengaruh nyata $(\mathrm{P}<0,05)$ terhadap kecernaan bahan kering dan bahan organik pada domba. Rataan total kecernaan bahan kering dan bahan organik ransum memperlihatkan adanya peningkatan kecernaan. Perlakuan fermentasi dan amoniasi memberikan pengaruh terbaik jika dibandingkan dengan tanpa pengolahan.
\end{abstract}

Kata kunci: Amoniasi, Domba, Fermentasi, Kecernaan bahan kering dan organik, Kulit singkong

\section{PENDAHULUAN}

Pakan berperan penting bagi produktivitas ternak. Ternak harus mendapatkan pakan yang berkualitas, murah, dan tersedia secara berkelanjutan sesuai dengan kebutuhannya. Kecukupan bahan pakan sampai saat ini masih menjadi pembatas untuk pengembangan usaha peternakan di Indonesia. Faktor terbatasnya ketersediaan bahan pakan yang ada karena lahan hijauan yang mulai hilang serta mahalnya bahan pakan ternak. Biaya yang harus dikeluarkan peternak untuk pakan dapat mencapai $60--70 \%$ dari total biaya produksi, sehingga peternak mengalami kesulitan dalam mengembangkan usaha peternakannya.

Domba ekor tipis merupakan jenis ternak ruminansia penghasil daging dengan pertumbuhan dan perkembangan yang cepat. Produksi daging yang dihasilkan suatu ternak dipengaruhi oleh 
bahan pakan yang dikonsumsi. Bahan pakan sebaiknya sudah didapat, terjangkau harganya, dan kandungan nilai nutrisinya baik. Permasalahan yang sering dihadapi dalam peningkatan kualitas dan kuantitas usaha peternakan di Indonesia adalah terbatasnya ketersediaan bahan pakan yang menjadi sumber utama ternak. Upaya pemanfaatan limbah hasil pertanian sebagai sumber pakan alternatif merupakan langkah yang tepat dalam menekan biaya pakan.

Singkong merupakan tanaman yang memiliki banyak manfaat selain sebagai salah satu sumber bahan pokok, namun potensi yang terkandung dalam tanaman singkong belum dimanfaatkan secara maksimal. Menurut Badan Pusat Statistik (2015), produksi ubi kayu di Lampung sebesar 7,387,084 juta ton/tahun, dan menghasilkan limbah 1,18 juta ton kulit singkong yang belum dimanfaatkan atau terbuang. Kulit singkong memiliki potensi yang besar sebagai bahan pakan alternatif karena harganya yang murah, ketersediaannya banyak, dan mudah didapat, serta tidak bersaing dengan manusia. Kulit singkong juga memiliki kandungan yang baik seperti karbohidrat yang tinggi. Marjuki et al. (2005) menyatakan bahwa kulit ketela pohon mengandung BETN 68,5\%. Hal ini menunjukkan bahwa kandungan karbohidrat terlarutnya cukup tinggi. Limbah kulit singkong tersebut memiliki kualitas yang kurang baik untuk dijadikan bahan pakan ternak dikarenakan masih tingginya kadar serat kasar dan mengandung HCN (asam sianida) yang berbahaya jika dikonsumsi ternak. Asam sianida $(\mathrm{HCN})$ merupakan zat yang bersifat racun baik dalam bentuk bebas maupun kimia (Coursey, 1973). Proses fermentasi maupun amoniasi perlu dilakukan untuk menurunkan serat kasar dan meningkatkan nutrisi yang lain. Berdasarkan uraian di atas, perlu dilakukan penelitian tentang pengolahan kulit singkong berupa fermentasi dan amoniasi sebelum digunakan sebagai pakan ternak domba dan pengaruhnya terhadap kecernaan ternak domba.

\section{MATERI DAN METODE}

\section{Materi}

Bahan penelitian yang digunakan yaitu 9 ekor domba ekor tipis jantan. Ransum penelitian yang digunakan terdiri atas limbah kulit singkong, hijauan (silase daun singkong), konsentrat (onggok, dedak halus, bungkil kelapa sawit, molasses), dan air sumur. Pada penelitian ini digunakan 9 unit kandang kambing individu yang dilengkapi dengan tempat pakan, waring penampung feses, timbangan gantung digital, sekop, sapu lidi, ember, kantung plastik, buku tulis, pena, terpal, karung, dan drum plastik.

\begin{abstract}
Metode
Rancangan Percobaan

Penelitian menggunakan metode in vivo dengan Rancangan Acak Lengkap (RAL). Perlakuan terdiri atas 3 ekor domba jantan dan menggunakan 3 ulangan dengan bobot tubuh berkisar $\pm 15 \mathrm{~kg} /$ ekor. Perlakuan yang diberikan antara lain ransum basal $+15 \%$ kulit singkong tanpa pengolahan (R0), ransum basal $+15 \%$ kulit singkong fermentasi (R1), dan ransum basal $+15 \%$ kulit singkong amoniasi (R2).
\end{abstract}

\section{Peubah yang Diukur}

Peubah yang diukur pada penelitian ini adalah menghitung kecernaan bahan kering (KCBK) dan kecernaan bahan organik (KCBO) ransum. Pengukuran kecernaan bahan kering (KCBK) berdasarkan rumus Tillman et al. (1991) berikut:

$K C B K(\%)=\frac{\sum B K \text { yang dikonsumsi }(g)-\sum B K \text { dalam feses }(g)}{\sum B K \text { yang dikonsumsi }(g)} \times 100 \%$

Pengukuran kecernaan bahan organik (KCBO) berdasarkan rumus Tillman et al. (1991) berikut:

$$
K C B O(\%)=\frac{\sum B O \text { yang dikonsumsi }(g)-\sum B O \text { dalam feses }(g)}{\sum B O \text { yang dikonsumsi }(g)} \times 100 \%
$$

Kecernaan dihitung berdasarkan rumus Tillman et al. (1991) berikut: $\frac{\sum \text { Zat makanan yang dikonsumsi }(\mathrm{g})-\sum \text { Zat makanan dalam feses }(\mathrm{g})}{\sum \text { Zat makanan yang dikonsumsi }(\mathrm{g})} \times 100 \%$

\section{Prosedur Penelitian}

Penelitian ini dilaksanakan melalui beberapa tahapan, yaitu persiapan kandang lengkap dengan peralatan operasional kandang; persiapan pakan dengan pembuatan fermentasi dan amoniasi kulit singkong. Masa adaptasi domba dilakukan selama 14 hari untuk penyesuaian terhadap ransum perlakuan. Pemeliharaan dilakukan selama 8 minggu dengan pemberian pakan sebanyak 2 kali sehari. Pakan yang diberikan terdiri dari ransum basal (onggok, dedak halus, bungkil kelapa sawit, dan molases) yang ditambahkan dengan ransum tiap perlakuan. Koleksi feses dilakukan 1x24 jam selama 7 hari setelah konsumsi domba sudah konsisten. Selanjutnya dilakukan analisis proksimat feses dan menghitung KCBK dan KCBO.

\section{Analisis Data}

Data yang diperoleh dianalisis dengan Analisis of Variant (ANOVA). Apabila hasil analisis berpengaruh nyata pada suatu peubah maka analisis dilanjutkan dengan uji beda nyata terkecil (BNT) pada taraf nyata $5 \%$ dan $1 \%$. 


\section{HASIL DAN PEMBAHASAN}

\section{Pengaruh Perlakuan terhadap Kecernaan Bahan Kering (KCBK) Ransum pada Domba Jantan.}

Nilai rataan pengaruh perlakuan terhadap

kecernaan bahan kering ransum dapat dilihat pada Tabel 1. Hasil analisis ragam menunjukkan bahwa perlakuan R1 (fermentasi) dan R2 (amoniasi) berpengaruh nyata $(\mathrm{P}<0,05)$ dalam meningkatkan nilai kecernaan bahan kering ransum pada domba jika dibandingkan dengan R0 (kontrol). Hasil uji lanjut BNT yang kemudian dilakukan juga menunjukkan nilai kecernaan bahan kering ransum pada perlakuan R1 dan R2 masih berpengaruh nyata $(\mathrm{P}<0,05)$ meningkatkan kecernaan bahan kering ransum dibandingkan perlakuan R0. Hal tersebut dikarenakan perlakuan R1 dan R2 dapat meningkatkan protein, menurunkan kandungan lignin, dan merubah komponen kompleks pada kulit singkong menjadi komponen yang lebih sederhana.

Tabel 1. Pengaruh perlakuan terhadap kecernaan bahan kering ransum

\begin{tabular}{|c|c|c|c|}
\hline \multirow{3}{*}{ Ulangan } & \multicolumn{3}{|c|}{ Perlakuan } \\
\hline & R0 & R1 & R2 \\
\hline & \multicolumn{3}{|c|}{ 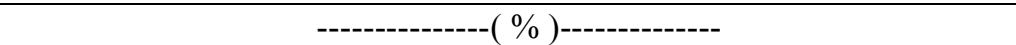 } \\
\hline 1 & 65,76 & 73,09 & 68,71 \\
\hline 2 & 63,29 & 70,63 & 69,73 \\
\hline 3 & 60,91 & 68,58 & 73,75 \\
\hline Rata-rata & $63,32 \pm 2,42^{\mathrm{a}}$ & $70,77 \pm 2,26^{b}$ & $70,73 \pm 2,67^{b}$ \\
\hline
\end{tabular}

Keterangan: nilai dengan huruf superskrip yang berbeda pada baris yang sama menunjukkan berbeda nyata $(\mathrm{P}<0,05)$ berdasarkan Uji BNT.

R0: Ransum basal $+15 \%$ kulit singkong tanpa pengolahan

$\mathrm{R} 1$ : Ransum basal $+15 \%$ kulit singkong fermentasi

$\mathrm{R} 1$ : Ransum basal $+15 \%$ kulit singkong amoniasi

Perlakuan fermentasi pada kulit singkong dapat meningkatkan protein dan mengubah komponen kulit singkong menjadi lebih sederhana. Hal ini didukung oleh Kompiang et al. (1994) yang menyatakan bahwa proses fermentasi dapat meningkatkan zat-zat makanan seperti protein dan energi metabolis serta mampu memecah komponen kompleks menjadi komponen sederhana. Proses fermentasi menggunakan EM4 juga dapat mengubah tekstur kulit singkong menjadi lebih lunak sehingga dapat meningkatkan daya cerna dari ternak domba. Sesuai dengan pendapat Soetanto (2007) yang menyatakan bahwa bakteri selulotik dari starter EM4 menghasilkan enzim yang dapat menghidrolisis ikatan glukosida 1-4 selulosa dan dimer selobiosa, sehingga tekstur serat sawit menjadi lebih lunak dan daya cerna dari ternak ruminansia dapat meningkat. Tanuwijaya (1987) menambahkan bahwa degradasi secara mikrobiologis yang terjadi pada saat proses fermentasi merupakan salah satu cara yang dapat mengubah bahan yang mengandung komponen serat seperti selulosa dan lignin menjadi bahan berguna seperti monosakarida, disakarida atau selubiosa.

Pada perlakuan fermentasi juga terdapat tambahan bakteri, fungi dan Actinomycetes dari EM4. Bakteri, fungi, dan Actinomycetes dapat memproduksi enzim selulase yang mampu menurunkan kadar serat kasar serta meningkatkan kecernaan. Santoso dan Aryani (2007) menyatakan bahwa EM4 merupakan campuran kultur yang mengandung Lactobacillus, jamur fotosintetik, bakteria fotosintetik, Actinomycetes serta ragi yang mampu menurunkan kadar serat kasar dan meningkatkan kecernaan bahan pakan. Mackie et al. (2002) menambahkan bahwa adanya aktivitas mikroba dalam saluran pencernaan sangat mempengaruhi kecernaan. Khoiriyah et al. (2016) menyatakan bahwa tingkat kecernaan pada ruminansia dipengaruhi oleh populasi mikroba di dalam rumen.

Perlakuan amoniasi pada kulit singkong juga dapat meningkatkan kadar protein kasar dalam ransum. Kadar protein kasar ransum pada perlakuan R2 (9,83\%) lebih tinggi jika dibandingkan dengan perlakuan R0 $(9,05 \%)$. Sesuai dengan pernyataan Hanifah et al. (2010), bahwa dengan amoniasi 3\% bahan kering (BK) kulit singkong dapat meningkatkan protein kasar (PK) dari 5,48\% menjadi $17,8 \%$. Perlakuan amoniasi yang menggunakan urea juga dapat menghancurkan ikatan-ikatan lignin. Salah satu faktor yang menyebabkan rendahnya daya cerna suatu bahan pakan adalah kandungan lignin, selulosa, dan silika yang terdapat di dalam bahan pakan. Sesuai dengan pendapat Chenost (2007) bahwa urea dalam proses 
amoniasi berfungsi untuk menghancurkan ikatanikatan lignin, selulosa, dan silika yang merupakan faktor penyebab rendahnya daya cerna jerami bagi ternak. Regan (2007) menjelaskan bahwa manfaat amoniasi adalah merubah tekstur jerami yang semula keras menjadi lunak. Prasetyawan et al. (2012) menyatakan bahwa perlakuan amoniasi dapat meningkatkan kecernaan dengan melonggarkan ikatan lignoselulosa, menjadikan karbohidrat mudah dicerna, dan meningkatkan kecernaan dengan membengkakkan jaringan tanaman.

Nilai kecernaan bahan kering juga dapat dipengaruhi oleh kandungan bahan kering yang terdapat pada ransum. Ransum perlakuan R1 dan R2 memiliki kadar bahan kering 89,99\% dan $89,86 \%$. Kandungan bahan kering ransum perlakuan R1 dan R2 lebih tinggi jika dibandingkan dengan ransum perlakuan R0 $(89,42 \%)$. Banyaknya kandungan bahan kering yang terdapat pada ransum dapat meningkatkan kecernaan bahan kering ransum pada ternak. Sesuai dengan pernyataan Tillman et al. (1998) bahwa faktor yang mempengaruhi tingkat kecernaan bahan kering salah satunya adalah jumlah bahan kering yang dikonsumsi karena aktivitas mikroba mengikuti bahan pakan yang dikonsumsi. Oleh karena itu, dengan adanya perlakuan fermentasi dan amoniasi pada kulit singkong dapat meningkatkan kerja mikroba yang ada di dalam rumen.

Kecernaan pada ternak ruminansia sangat dipengaruhi oleh kandungan serat kasar suatu bahan pakan yang dikonsumsi. Serat kasar tersebut nantinya akan mempengaruhi kinerja mikroba yang terdapat dalam saluran pencernaan ruminansia untuk melakukan proses pencernaan. Putra (1999) menyatakan bahwa kecernaan nutrien pakan secara in vivo pada ternak ruminansia ditentukan oleh kandungan serat kasar pakan (faktor eksternal) dan aktivitas mikroba rumen (faktor internal), terutama bakteri dan interaksi antara kedua faktor tersebut.

\section{Pengaruh Perlakuan terhadap Kecernaan Bahan} Organik (KCBO) Ransum pada Domba Jantan

Nilai rataan pengaruh perlakuan terhadap kecernaan bahan organik ransum dapat dilihat pada Tabel 2. Hasil analisis ragam menunjukkan perlakuan R1 (fermentasi) dan R2 (amoniasi) berpengaruh nyata $(\mathrm{P}<0,05)$ meningkatkan nilai kecernaan bahan organik ransum pada domba jika dibandingkan dengan R0 (kontrol).

Tabel 2. Pengaruh perlakuan terhadap kecernaan bahan kering ransum

\begin{tabular}{cccc}
\multirow{2}{*}{ Ulangan } & \multicolumn{3}{c}{ Perlakuan } \\
\cline { 2 - 4 } & R0 & R1 & R2 \\
\cline { 2 - 4 } & & $------------(\%)$------------ & 71,17 \\
2 & 68,63 & 75,62 & 72,01 \\
3 & 66,51 & 73,67 & 75,83 \\
\hline Rata-rata & 64,02 & 72,01 & $73,00 \pm 2,49^{\mathrm{b}}$ \\
\hline
\end{tabular}

Keterangan: nilai dengan huruf superskrip yang berbeda pada baris yang sama menunjukkan berbeda nyata $(\mathrm{P}<0,05)$ berdasarkan Uji BNT.

R0: Ransum basal $+15 \%$ kulit singkong tanpa pengolahan

$\mathrm{R} 1$ : Ransum basal $+15 \%$ kulit singkong fermentasi

R2: Ransum basal $+15 \%$ kulit singkong amoniasi

Hal ini menunjukkan bahwa peningkatan kecernaan bahan kering ransum selalu diiringi dengan kecernaan bahan organiknya. Fathul dan Wajizah (2010) menyatakan bahwa bahan organik merupakan bagian dari bahan kering, sehingga apabila bahan kering meningkat akan meningkatkan bahan organik begitu juga sebaliknya.

Hasil uji lanjut BNT menunjukkan bahwa hasil kecernaan bahan organik ransum pada perlakuan $\mathrm{R} 1$ dan $\mathrm{R} 2$ berpengaruh nyata $(\mathrm{P}<0,05)$ terhadap perlakuan $\mathrm{R} 0$. Hal tersebut dikarenakan pada perlakuan R1 terdapat adanya penggunaan bakteri dari EM4. Mikrobia pada EM4 mampu mencerna komponen serat kasar yang terkandung pada kulit singkong secara optimal. Hal tersebut sesuai dengan pendapat Arifin (2003) bahwa EM4 adalah campuran kultur yang mengandung Lactobacillus, jamur fotosintetik, bakteria fotosintetik, Actinomycetes, dan ragi. Kandungan serat kasar dalam pakan akan menyebabkan rendahnya nilai degradasi, karena serat kasar yang berupa selulosa dan hemiselulosa sering berikatan dengan lignin dan akan sulit untuk dipecah oleh enzim pencernaan (Tillman et al., 1991). Adanya bantuan mikrobia di dalam EM4 yang terdapat pada perlakuan R1 menyebabkan komponen serat kasar yang terkandung pada kulit singkong dapat tercerna secara optimal. Penambahan inokulum pada R1 dapat menyebabkan pertumbuhan bakteri pada substrat semakin banyak, sehingga aktivitas enzim 
juga meningkat dalam mengurai komponen serat menjadi molekul yang lebih sederhana. Sandi et al. (2013) menyatakan bahwa penambahan inokulum akan semakin mempercepat proses fermentasi dan semakin banyak substrat yang didegradasi.

Perlakuan amoniasi pada kulit singkong dapat menurunkan kandungan serat kasar (SK). Kandungan SK dalam pakan akan menyebabkan rendahnya nilai degradasi, karena SK yang berupa selulosa dan hemiselulosa sering berikatan dengan lignin dan akan sulit untuk dipecah oleh enzim pencernaan. Sesuai pendapat Chenost (2007) bahwa urea dalam proses amoniasi berfungsi untuk menghancurkan ikatan-ikatan lignin, selulosa, dan silika yang merupakan faktor penyebab rendahnya daya cerna jerami bagi ternak. Prasetyawan et al. (2012) juga menyatakan bahwa perlakuan amoniasi dapat meningkatkan kecernaan dengan melonggarkan ikatan lignoselulosa, menjadikan karbohidrat mudah dicerna, dan meningkatkan kecernaan dengan membengkakkan jaringan tanaman. Tillman et al. (1998) menyatakan bahwa kecernaan bahan organik juga dipengaruhi oleh kandungan serat kasar dalam bahan pakan sebab kandungan serat kasar dalam pakan akan mengakibatkan rendahnya nilai degradasi, karena serat kasar yang berupa selulosa dan hemiselulosa sering berikatan dengan lignin dan akan sulit untuk dipecah oleh enzim pencernaan, dengan demikian kecernaan akan semakin rendah apabila suatu bahan pakan mengandung serat yang tinggi.

Perlakuan R0, R1, dan R2 memiliki kandungan serat kasar 13,87\%, 13,64\%, 13,55\%. Kandungan serat kasar tertinggi terdapat pada perlakuan R0 jika dibandingkan dengan perlakuan lainnya. Hal tersebut menunjukkan bahwa perlakuan R1 dan R2 dapat menurunkan kandungan serat kasar pada kulit singkong. Sesuai dengan pendapat Komar (1984), bahwa fermentasi menggunakan starter EM4 dapat mendegradasi serat kasar dan merenggangkan ikatan lignoselullosa, sehingga tekstur dari amofer serat sawit menjadi halus. Hastuti et al. (2011) juga menyatakan bahwa amoniasi berfungsi memutuskan ikatan antara selulosa dan lignin, serta membuat ikatan serat menjadi longgar. Rendahnya kandungan serat kasar pada perlakuan R1 dan R2 membuat keceranaan bahan organik semakin tinggi.

Kecernaan bahan organik juga dipengaruhi oleh kandungan bahan organik yang terkandung dalam ransum. Bahan organik merupakan komponen penyusun bahan kering. Komposisi bahan organik terdiri dari lemak, protein kasar, serat kasar dan BETN. Kandungan bahan organik ransum pada perlakuan R0, R1, dan R2 yaitu $82,24 \%, 82,08 \%, 81,35 \%$. Semakin tinggi kandungan bahan organik pada ransum maka kecernaannya akan semakin meningkat. Hal ini sesuai dengan pernyataan Wodzicka et al. (1991) bahwa tinggi rendahnya kecernaan bahan organik disebabkan oleh tinggi rendahnya konsumsi bahan organiknya. Besarnya konsumsi bahan organik ini akan mempengaruhi ketersediaan energi dalam rumen untuk pertumbuhan mikroba rumen. Pertumbuhan mikroba rumen akan berhubungan dengan kerja optimal mikroba yang nantinya berpengaruh terhadap kecernaan ternak (Kamal, 1994). Sehingga konsumsi bahan organik akan berbanding lurus dengan kecernaan bahan organiknya.

Kadar abu pada ransum perlakuan kulit singkong R0, R1, dan R2 yaitu 7,18\%; 7,91\%; $8,52 \%$. Kandungan abu terendah terdapat pada perlakuan R0 sedangkan perlakuan R1 dengan R2 memiliki kandungan abu yang tidak jauh berbeda. Tinggi rendahnya kecernaan bahan organik akan dipengaruhi oleh kandungan abu yang terdapat dalam pakan atau ransum. Sehingga jika kandungan abu dalam pakan atau ransum tinggi maka akan menurunkan nilai kercernaan bahan organik. Hal ini sesuai dengan pernyataan Fathul dan Wajizah (2010) yang menyatakan bahwa kandungan abu dapat memperlambat atau menghambat tercernanya bahan organik pada ransum.

Perlakuan R0 memiliki kadar abu terendah namun nilai kecernaan bahan organiknya lebih rendah jika dibandingkan dengan perlakuan R1 dan R2. Hal tersebut dikarenakan kandungan serat kasar pada perlakuan R0 lebih tinggi jika dibandingkan dengan perlakuan R1 dan R2. Menurut pendapat Tillman et al. (1998), kecernaan bahan organik juga dipengaruhi oleh kandungan serat kasar dalam bahan pakan. Kandungan serat kasar dalam pakan akan mengakibatkan rendahnya nilai degradasi, karena serat kasar yang berupa selulosa dan hemiselulosa sering berikatan dengan lignin dan akan sulit untuk dipecah oleh enzim pencernaan. Kecernaan akan semakin rendah apabila suatu bahan pakan mengandung serat kasar yang tinggi.

Pada Tabel 2 terlihat bahwa nilai kecernaan bahan organik relatif lebih tinggi dibandingkan nilai kecernaan bahan kering (Tabel. 1) pada semua ransum perlakuan. Hal ini dikarenakan pada bahan kering masih mengandung abu, sedangkan bahan organik tidak mengandung abu. Bahan tanpa kandungan abu relatif lebih mudah dicerna dibandingkan bahan yang memiliki banyak kandungan abu. Kandungan abu dapat menghambat tercernanya bahan kering ransum. Sesuai pendapat Fathul dan Wajizah (2010), bahwa kandungan abu dapat memperlambat atau menghambat tercernanya bahan organik pada ransum. Yuhana et al. (2010) menambahkan bahwa semakin tinggi kecernaan bahan kering maka 
semakin meningkat kecernaan bahan organik dan semakin tinggi peluang nutrisi yang dapat dimanfaatkan ternak untuk produksi.

\section{SIMPULAN}

Berdasarkan penelitian yang telah dilaksanakan dapat disimpulkan bahwa :

1. Perlakuan fermentasi (R1) dan amoniasi (R2) pada kulit singkong berpengaruh nyata $(\mathrm{P}<0,05)$ terhadap kecernaan bahan kering (KCBK) ransum dan kecernaan bahan organik (KCBO) ransum pada ternak domba jantan;

2. Rataan total kecernaan bahan kering dan bahan organik ransum memperlihatkan adanya peningkatan, dimana perlakuan R1 dan R2 memberikan pengaruh terbaik jika dibandingkan dengan perlakuan R0.

\section{DAFTAR PUSTAKA}

Arifin, S. 2003. Pengaruh Penggunaan Bekatul Fermentasi dengan EM4 (Efektif Mikroorganisme) dalam Ransum terhadap Efisiensi Pakan dan Income Over Feed Cost (Iofc) pada Ayam Potong (Broiler). Departement of Animal Husbandry. Universitas Muhammadiyah. Malang.

Badan Pusat Statistik. 2015. Statistik Indonesia. Badan Pusat Statistik. Jakarta.

Chenost. 2007. Teknologi Pengolahan Jerami Padi Sebagai Pakan Ternak. https://www. Academia.edu/ 20059642/.html. Diakses pada 23 Agustus 2019.

Coursey, D. G. 1973. Cassava as Food Toxicity and Technology. Prociding of Interdiciplinary Workshop. London. England. p.27-36.

Fathul, F. dan S. Wajizah. 2010. Penambahan Mikromineral Mn dan Cu dalam Ransum terhadap Aktivitas Biofermentasi Rumen Domba secara In Vitro. JITV. 15(1): 9-15.

Hanifah, V. W., D. Yulistiani, dan S. A. A. Asmarasari. 2010. Optimalisasi Pemanfaatan Limbah Kulit Singkong menjadi Pakan Ternak dalam Rangka Memberdayakan Pelaku Usaha EnyeEnye. Prosiding Seminar Nasional. Teknologi Peternakan dan Veteriner. Balai Penelitian Ternak. Bogor.

Hastuti, D., N. A. Shofia, dan I. M. Baginda. 2011. Pengaruh Perlakuan Teknologi Amofer (Amoniasi Fermentasi) pada Limbah Tongkol Jagung sebagai Alternatif Pakan Berkualitas Ternak Ruminansia. J. Ilmu-Ilmu Peternakan Mediagro. 7(1): 55-65.
Kamal, M. 1994. Nutrisi Ternak. Fakultas Peternakan. Universitas Gajah Mada. Yogyakarta.

Khoiriyah, M., C. Siti, dan S. Herni. 2016. Effect of Flour and Papaya Leaf Extract (Carica papaya L.) Caddition to Feed on Gas Production, Digestibility and Energy Values In Vitro. J. Ternak Tropika 17(2): 74-85.

Komar, A. 1984. Teknologi Pengolahan Jerami sebagai Makanan Ternak. Yayasan Dian Grahita. Bandung.

Kompiang, L. P., J. Dharma., T. Purwadaria., A. Sinurat, dan Supriyati. 1994. Protein Enrichment: Study Cassava Enrichment melalui Bioproses Biologi untuk Ternak Monogastrik. Kumpulan Hasil-Hasil Penelitian. Balai Penelitian Ternak. Bogor.

Mackie, R. I., C.S. McSweeney, and A.V. Klieve. 2002. Microbial Ecology of Theovine Rumen. In: Sheep Nutrition. M. Freer and H. Dove (Ed). Plant Industry. Canberra. Australia. p.73-80.

Marjuki, Soebarinoto, dan W. H. Utomo. 2005. The Use of Cassava Roots and Leaves in Livestock Feeding in Indonesia. In: The Use of Cassava Roots and Leaves For on Farm Animal Feeding. R. H. Howeler. Proceeding of A Regional Workshop. Hue City. Vietnam.

Prasetyawan, R. M., B. I. M. Tampoebolon, dan Surono. 2012. Peningkatan Kualitas Tongkol Jagung melalui Teknologi Amoniasi Fermentasi (Amofer) terhadap Kecernaan Bahan Kering dan Bahan Organik serta Protein Total Secara In Vitro. J. Animal Agriculture. 1 (1): 611621.

Putra, S. 1999. Peningkatan Performans Sapi Bali melalui Perbaikan Mutu Pakan dan Suplementasi Seng Asetat. Disertasi. Program Pascasarjana. Institut Pertanian Bogor. Bogor.

Regan, C. S. 2007. Forage Concervation in The Wet/Dry Tropics for Small Landholder Farmers. Thesis. Faculty of Science. Nothern Territory University. Darwin Australia.

Sandi, Y. O., S. Rahayu, dan S. Wardhana. 2013. Upaya Peningkatan Kualitas Kulit Singkong melalui Fermentasi Menggunakan Leuconostoc mesenteroides Pengaruhnya terhadap Kecernaan Bahan Kering dan Bahan Organik secara In Vitro. J. Ilmiah Peternakan. 1(1): 99-108.

Santoso, U. dan Aryani, I. 2007. Perubahan Komposisi Kimia Daun Ubi Kayu yang 
Difermentasi oleh EM4. J. Sains Peternakan Indonesia. 2(2):53-56.

Soetanto, H. 2007. Buku Ajar Nutrisi Ruminansia. Jurusan Nutrisi dan Makanan Ternak. Fakultas Peternakan. Universitas Brawijaya. Malang.

Tillman, A. D., H. Hartadi., S. Reksohadiprojo., S. Prawirokusumo, dan S. Lebdosoekojo. 1998. Ilmu Makanan Ternak Dasar. Universitas Gadjah Mada. Yogyakarta. 1991. Ilmu Makanan Ternak Dasar. Universitas Gadjah Mada. Yogyakarta.

Tanuwidjaya, L. 1987. The Effect of Mineral Salt on Protein Enrichment of CassavaSolidwaste by Solid Substrate Fermentation. In: Proceeding Bioconversion Project Second Workshop on Crop Residues for Feed and Other Purpose. M. Soejono, A. Musofie, R. Utomo, N. K. Wardhani dan J. B. Schiere (Ed). Grati. P.301-306.

Wodzicka,T. M., I. K. Sutama., I. Putu, dan T. D. Chaniago. 1991. Tingkah Laku dan Produksi Ternak di Indonesia. Gramedia Pustaka Utama. Jakarta.

Yuhana, S. A., W. D. Jayanti., A.T. Purwitasari, dan A. Kharisma. 2010. Antibakterial Ekstrak Daun Kemangi (Ocimum sanctum Linn) terhadap Bakteri Aeromonas hydrophila secara In Vitro. Universitas Airlangga. Surabaya. 